\title{
Innovative design of ironing board based on Kansei Engineering and usability test
}

\author{
Nadia Zhafira, Perdana Suteja Putra, Fety Ilma Rahmillah, and Amarria Dila Sari* \\ Department of Industrial Engineering, Islamic University of Indonesia, Yogyakarta, Indonesia
}

\begin{abstract}
Laundry business is popular service business in Indonesia that mostly involve muscle activity for lifting and ironing activity. It causes the worker get muscular fatigue and injury especially for ironing activity that is included in the static and monotonous activity. moreover, existed ironing board design in the market is not easy to be adjusted to standing or sitting position of workers. Hence, this paper aimed to design the innovative and adjustable ironing board to minimize the musculoskeletal complaint. The preliminary study is conducted by NBM questionnaires found that fatigue experienced mostly in the back, right upper arm, and calves. The product designed by Kansei engineering to satisfy consumer's feeling and assessed by USE questionnaire to fulfil consumer's usability. Orthogonal array and conjoint analysis were conducted to incorporate all attribute potentials in developing a new single concept design. Statistical analysis was also done to test the hypothesis. 80 respondents have participated in this study. The result of this study is an innovative design of ironing board which is valid to meet consumers' needs such as comfort, secure, attractive, sturdy, durable and multifunction and practical at $5 \%$ of the significant level.
\end{abstract}

\section{Introduction}

One of success standard in developed country is its prosperous [1]. The prosperous is identified based on its society including the role of workers in existed industry. moreover, female worker commonly supports the economic growth of family in order to reach the prosperous condition. In fact, recently the number of female workers is increased in two cases which are necessity and choice [2]. In addition, female workers are mostly worked for the informal sector such as laundry industry [3]. As found that laundry industry has been growing in many towns in Indonesia.

The laundry industry developed in many towns where there are many students, workers, and households using the laundry services to facilitate everyday activities [4]. Especially in Jogjakarta, the industrial development is also due to tourism and education that can increase the economic development and employment equity. Laundry workers have responded in weighing and sorting dirty clothes, washing, drying, ironing, and customer services that limited to certain conditions [5]. Workers have to do the job in limited time due to the deadline of customer pick up and face different customer characteristics. This condition leads to musculoskeletal disorders such as while lifting the bucket of laundry and drying the clothes by ironing. Ironing is the most exhausting and riskiest activity among other work processes and workers feel a pain of the waist and arm after did it [6,7]. Moreover, most of them work eight to fifteen hours per day [7].

The musculoskeletal disorders are mostly caused by static and monotony work, a station which is unfit with the workers' anthropometry, a long duration, and heat posed because of the ironing tool [8]. Moreover, study by [9] shows that this complaint is dominantly by $57 \%$ for low back pain. This condition is at high risk and need improvement based on posture assessment [6]. On the other measurement, it stated that complaint in ironing activity is felt by hand, knee, elbow, arm, and shoulder [4]. Hence, one of the methods used to minimize the users' complaint is redesigning the equipment used by workers such as ironing board. This innovative design has to meet users' expectation in addition to a favourable impression or Kansei.

Kansei is a Japanese word which has multi-faceted expression and it is the impression somebody gets from a certain artefact, environment or situation using all the senses of sight, hearing, feeling, smell, taste as well as recognition [10,11]. Kansei Engineering (KE) is one method to take into account human feeling or emotion to translate it into design elements [12]. Thus, KE is a proper method in developing products which provide a way to realize human feelings into products.

Some previous researchers applied KE to develop consumers' product design such as sunglasses selection [13], design of baby bags based on the principle of Kansei Engineering in combination with fuzzy linguistic method [14], and design of maternity pillow [18]. However, the usage of $\mathrm{KE}$ and its combination with usability test are rarely used. Therefore, this study aimed to design innovative ironing board in order to minimize the musculoskeletal disorders complaint based on users' feeling and usability.

\footnotetext{
*Corresponding author: amarria@uii.ac.id
} 


\section{Research Methodology}

\subsection{Nordic Body Map}

In order to strengthen the statement that ironing activity leads to musculoskeletal disorders for the users because of its posture, supporting method is needed. Nordic Body Map questionnaire is chosen as the supporting method in order to determine the parts of muscle experiencing symptoms ranging from discomfort to very discomfort [15]. Nordic Body Map questionnaire uses the image of the human body which is divided into 9 main body parts that are the neck, shoulders, upper back, elbows, lower back, hips, knees, and ankles. From 9 body parts are then broken down into 28 parts of the body map questionnaire which distributed into 30 respondents who did standing position as their ironing activity position. In NBM questionnaire, the respondents should fill the checklist boxes which represent the grade of pain that they felt in each part of the body. The table 1 below shows the description of the grade of pain in NBM.

Table 1. Grade of Pain Description

\begin{tabular}{cc}
\hline Symbol & Description \\
\hline A & No Pain \\
B & Moderately Pain \\
C & Painful \\
D & Very Painful \\
\hline
\end{tabular}

\subsection{Kansei Engineering}

In this study, 50 respondents of laundry workers and housewives in Sleman, Yogyakarta that have been experienced laundry activity for more than 1 year are being interviewed. In addition, the object of this study is user complaints, feelings and requirements, body dimensions, and experience.

There are three main steps in this study to design the ironing board which conducted by the laundry workers. Those main steps are Kansei Engineering which consists of Kansei word collection, Semantic differential scale questionnaire, and sufficiency, validity, and reliability data test. After the valid user's feelings are collected, those aspects are being converted into product requirements. The next step in this study is product visualization with $3 \mathrm{D}$ design based on product requirements which has been obtained. Then, usability testing was conducted at the end of this study in order to test the usability aspects which consists of usefulness, ease of use, ease of learning, and user satisfaction of the ironing board design.

\subsection{Research Procedures}

The design process of this study has followed several steps as in Figure 1. The Nordic Body Map questionnaires is distributed in order to identify the muscle complain for ironing board activity. Then, Kansei words was collected to subjects aimed to know the customer's need of product. Furthermore, the Kansei words was proceed based on
Kansei Engineering process type I which is semantic differential and statistical analysis.

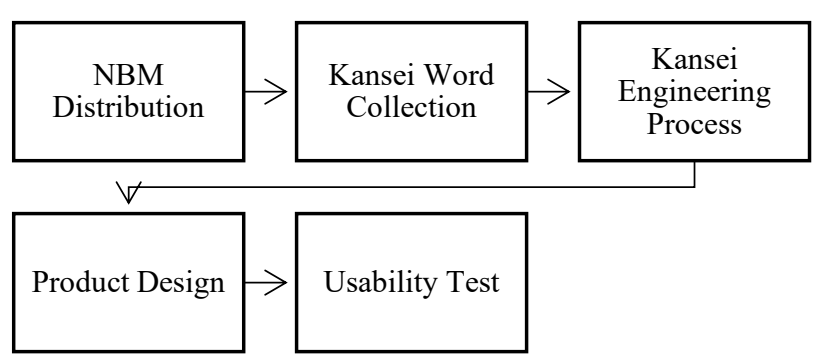

Fig. 1. Research procedures

Based on the result of analysis, the product was designed by researchers representatively. Moreover, in order to assess the usability of design, the usability test was designed based on the USE questionnaire.

\section{Results and Discussion}

\subsection{Nordic Body Map}

Most of the complaints that arise in the ironing activity are because the ironing activity tended to be static and monotony, and they felt fatigue in their back which can lead to musculoskeletal disorders. Nordic Body Map questionnaire is chosen as the supporting method in order to strengthen the background statement that ironing activity leads to musculoskeletal disorders for the users because of its posture. From 28 body parts based on the questionnaire that was already given to 30 respondents, most of the respondents feel pain in their back and right upper arm and feel moderate pain on their calves when the ironing activity taking too much time. The result of the NBM questionnaire is shown in Table 2.

Table 2. Nordic body map questionanire result

\begin{tabular}{|c|c|c|c|c|c|c|c|c|c|}
\hline \multirow{3}{*}{ No } & \multirow{3}{*}{ Location } & \multicolumn{8}{|c|}{ Grade of Complaints } \\
\hline & & \multicolumn{2}{|c|}{$\mathbf{A}$} & \multicolumn{2}{|c|}{ B } & \multicolumn{2}{|c|}{ C } & \multicolumn{2}{|c|}{ D } \\
\hline & & $\stackrel{\overrightarrow{0}}{\stackrel{0}{\Xi}}$ & $\%$ & $\stackrel{\overrightarrow{0}}{\stackrel{\overrightarrow{0}}{0}}$ & $\%$ & $\stackrel{\overrightarrow{0}}{\stackrel{D}{ٍ}}$ & $\%$ & $\stackrel{\overrightarrow{0}}{\stackrel{0}{0}}$ & $\%$ \\
\hline 5 & Back & 1 & $3 \%$ & 6 & $20 \%$ & 23 & 77 & 0 & $0 \%$ \\
\hline 6 & $\begin{array}{l}\text { Right } \\
\text { upper }\end{array}$ & 0 & $0 \%$ & 7 & $23 \%$ & 23 & $\begin{array}{l}\% \\
77 \\
\%\end{array}$ & 0 & $0 \%$ \\
\hline 22 & $\begin{array}{l}\text { Left } \\
\text { calf }\end{array}$ & 4 & $13 \%$ & 18 & $60 \%$ & 8 & $\begin{array}{l}27 \\
\%\end{array}$ & 0 & $0 \%$ \\
\hline 23 & $\begin{array}{l}\text { Right } \\
\text { calf }\end{array}$ & 4 & $13 \%$ & 18 & $60 \%$ & 8 & $\begin{array}{l}27 \\
\%\end{array}$ & 0 & $0 \%$ \\
\hline
\end{tabular}

\subsection{Kansei Engineering}

In designing the ironing board, Kansei Engineering are used as the initial step in order to obtain the user requirements based on their feelings. In this study, Kansei Engineering type- 1 is conducted in order to obtain the Kansei words. The Kansei word collected using open questionnaires that followed by semantic differential questionnaires. Based on the questionnaire spread, 7 Kansei words presented by consumers' voices were found. 
The words were tested by using fault tolerance of $5 \%$ as mentioned in Table 3.

Table 3. Kansei Words

\begin{tabular}{|c|c|c|c|}
\hline $\begin{array}{l}\text { Kansei } \\
\text { Words }\end{array}$ & Description & $\begin{array}{c}\text { Validity } \\
\text { Score }\end{array}$ & $\begin{array}{c}\text { Reliability } \\
\text { Score }\end{array}$ \\
\hline Comfort & $\begin{array}{c}\text { Provide } \\
\text { comfortable } \\
\text { design }\end{array}$ & 0.82430 & 0.869 \\
\hline Secure & $\begin{array}{l}\text { Has strong and } \\
\text { safe part }\end{array}$ & 0.82431 & 0.869 \\
\hline Practical & $\begin{array}{l}\text { Easy to be } \\
\text { brought and } \\
\text { simple } \\
\text { adjustment }\end{array}$ & 0.31182 & 0.95 \\
\hline Attractive & $\begin{array}{l}\text { Attract attention } \\
\text { by design and } \\
\text { colour }\end{array}$ & 0.38491 & 0.94 \\
\hline Sturdy & $\begin{array}{c}\text { Strong and solid } \\
\text { design }\end{array}$ & 0.82431 & 0.869 \\
\hline Durable & $\begin{array}{c}\text { Good quality of } \\
\text { material }\end{array}$ & 0.31182 & 0.95 \\
\hline Multifunction & $\begin{array}{l}\text { Has more than } \\
\text { one setting to be } \\
\text { used }\end{array}$ & 0.82440 & 0.869 \\
\hline
\end{tabular}

It shown on the result above that validity and reliability result gain more than $r$ table value $(0.284)$. it means that seven Kansei words are reliable and valid to be inputted as parameter design of ironing board. Hence, this product made was based on the psychological feelings of consumers which are comfort, secure, practical, attractive, sturdy, durable and has multifunction.

After the user's feelings are obtained, it can be converted into product requirements which can be continued to product design visualization. In determining the proper body dimension for the ironing board design, anthropometric percentile is used. Percentiles provide a basis for estimating the proportion of a population accommodated by a design. Thus, percentile can be applied to assess size limitations imposed by a design [16]. There are four dimensions which involved in this study; sum of thigh thickness (TP) and popliteal height (TPO) to determine the minimum height of the sitting ironing table, elbow height standing (TSB) to determine the maximum height of the standing ironing table, and arm's reach (JT) to determine the minimum ironing table length.

Figure 2 shows the side view of the ironing board design. The 5th percentile of elbow height standing (TSB) which gives value of $94.46 \mathrm{~cm}$ added by $4.5 \mathrm{~cm}$ as the allowance which gives $98.96 \mathrm{~cm}$ is chosen as the height of the standing ironing table. The 5th percentile of both thigh thickness (TP) and popliteal height (TPO) which gives value of $46.59 \mathrm{~cm}$ added by $4.5 \mathrm{~cm}$ as the allowance which gives $51.09 \mathrm{~cm}$ is chosen as height of sitting ironing table.

While figure 3 shows the top view of the ironing board design. The 95th percentile of arm's reach (JT) which gives value of $83.19 \mathrm{~cm}$ added by $4.5 \mathrm{~cm}$ as the allowance which gives $87.69 \mathrm{~cm}$ is chosen as the length of the sitting ironing table.

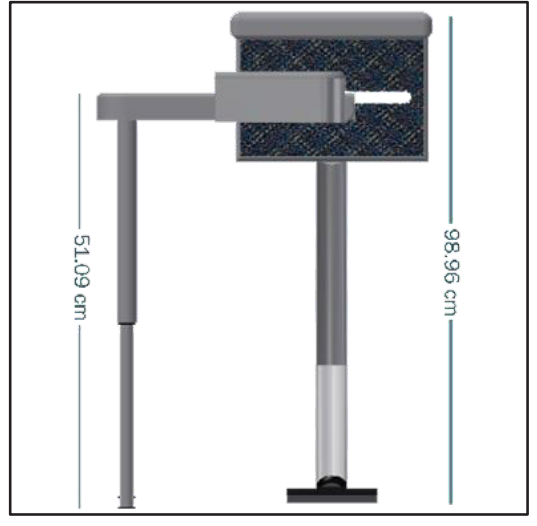

Fig. 2. Side view of ironing board design

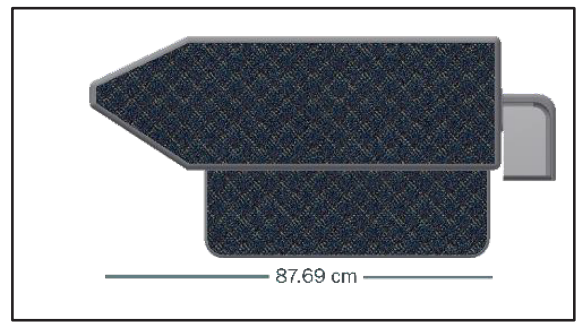

Fig. 3. Top view of ironing board design

Figure 4 below is the overall view of the ironing board design while the sitting position table is opened.

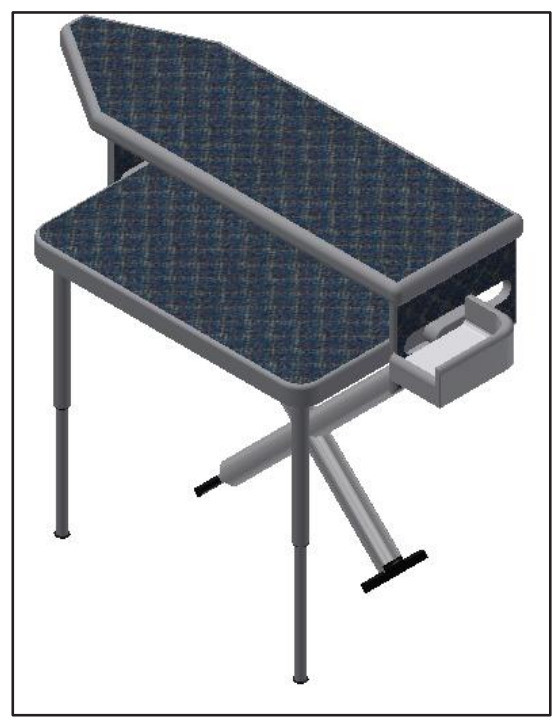

Fig. 4. Ironing board design isometric view

\subsection{Usability Testing}

In order to test the usability aspects in the design, usability testing is conducted. In usability testing, there are there are 3 independent variables (Usefulness, Ease of Use (X2), Ease of Learning) and 1 dependent variable (Satisfaction) which is assessed by USE questionnaires through the 50 respondents. After the data is collected, validity and reliability test should be performed first before analyze the usability of ironing board design. Based on the reliability test with $5 \%$ confidence interval, it shown that all of the data are valid and reliable and can 
be continued. The table below shows the result of usability test.

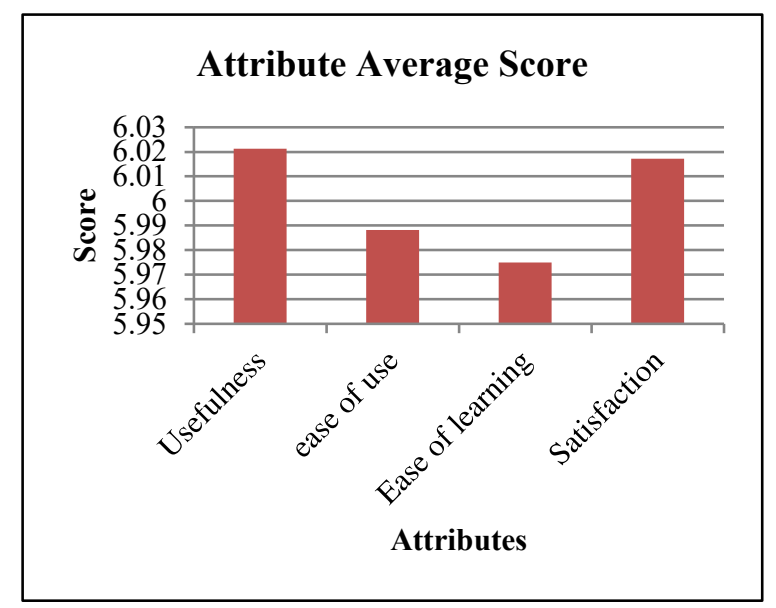

Fig. 5. Usability test result

Based on the result above, it can be found that Usefulness and Ease of Use variable have significant effect on the variable Satisfaction, while Ease of Learning did not affect satisfaction variables. It can be caused due to the product being tested is a product with a new innovation that is still unfamiliar to the user. However, looking at the average value of the Ease of Learning variable which is 5,975 out of a scale of 1 to 6 . This shows that the variable ease of learning can be tolerated because of the high level and the support level of satisfaction in the use of the product [17].

\section{Conclusion}

Most of the women workers in laundry business sector felt low back pain while ironing in a long period, it can lead to musculoskeletal disorders due to the static position in ironing activity. Innovative design of ironing table board is designed based on customer's feelings by using Kansei Engineering method. The Kansei words used as the specification of the design are comfort, secure, practical, attractive, sturdy, durable and multifunction. The recommendation product dimensions are $98.96 \mathrm{~cm}$ as the height of the standing ironing table, $51.09 \mathrm{~cm}$ as the height of sitting ironing table, and $87.69 \mathrm{~cm}$ as the length of the ironing table. USE questionnaire is used in order to test the usability aspects in the design with Usefulness, Ease of use, Ease of learning, and Satisfaction as the attributes.

\section{References}

1. P.M. Dewi, JEKT, 119-124 (2012)

2. H. Ware, Australian National University (1991)

3. N. Artini, Handayani, Piramida, 9-15 (2009)

4. A.D. Sari, M.R. Suryoputro, M.D. Pramaningtyas, P.S. Putra, S.B. Maulidyawati, IEEE Int. Conf. on Know. Eng. and Appl., 1-6 (2016)

5. OHSAH, Occ. Health Safety Agency for Healthcare in $B C$ (2003)

6. G.C. Angkoso, Unpublished Thesis, Faculty of Medicine and Public Health Islamic State University Syarif Hidayatullah (2012)

7. I.W. Ekawati, Proc. Int. Sem. Workshop on Pub. Health Act. (2015)

8. I. Dinata, N. Adiputra, I. Adiatmika. The Indonesian J. of Erg. 30-40 (2015)

9. Setyawati. Unpublished Thesis, Universitas Pembangunan Nasional Veteran (2003)

10. M. Nagamachi, App. Erg. 289-294 (2002)

11. M. Nagamachi, M. Tachikawa, N. Imanishi, T. Ishizawa, S. Yano, Linköping Elect. Conf. Proc. 234254 (2008)

12. M. Nagamachi, CRC Press (2011)

13. N.K. Chuan, A. Sivaji, M.M. Shahimin, N. Saad., Procedia-Soc. and Beh. Sci.97, 707-714 (2013)

14. H. Soewardi, M.I. Nasution, IOP Conf. Series: Mat. Sci. Eng. 165-171 (2016)

15. Corlett. Static Muscle Loading and the Evaluation of Posture, Taylor \& Francis (1992)

16. F. Tayyari, J.L. Smith, Occupational Ergonomics; Principles and applications, Kluwer Academic Publishers (1997)

17. V. Sahfitri, M. Ulfa, Proceeding SNaPP2014 Sci., Tech. and Health 373 (2014)

18. F.I. Rahmillah, R.N. Kartika, IOP Conf. Series: Mat. Sci. Eng. 215 (2017) 